\title{
Phenotypic variation associated with an anti- phagocytic factor in the bacterial fish pathogen Enterococcus seriolicida
}

\author{
T. Yoshida ${ }^{1, *}$, T. Eshima ${ }^{2}$, Y. Wada ${ }^{3}$, Y. Yamada ${ }^{1}$, E. Kakizaki $^{1}$, M. Sakai ${ }^{1}$, T. Kitao $^{1}$, \\ V. Inglis ${ }^{4}$ \\ ${ }^{1}$ Department of Fisheries, Faculty of Agriculture, Miyazaki University, Miyazaki 889-21, Japan \\ ${ }^{2}$ Asahi Chemical Industries, Oohito 632-1, Shizuoka, Japan \\ ${ }^{3}$ Nagajima Fisheries Industries, Saiki 876, Oita, Japan \\ ${ }^{4}$ Institute of Aquaculture, University of Stirling, Stirling FK9 4LA, Scotland, UK
}

\begin{abstract}
Enterococcus seriolicida is the causative agent of an enterococcal infection in yellowtail Seriola quinqueradiata and is antigenically classified into 2 phenotypes, KG+ and KG-. Phenotypic variation from $\mathrm{KG}$ - to $\mathrm{KG}+$ occurs readily on an artificial medium. The surface morphologies of the $\mathrm{KG}$ - and $\mathrm{KG}$ + phenotypes were differentiated by scanning electron microscopy. KG-cells were more hydrophilic than $\mathrm{KG}+$ cells and were resistant to phagocytosis by yellowtail head kidney phagocytes. The chemiluminescent response of these phagocytic cells was lower with the KG-phenotype than with the $\mathrm{KG}+$ phenotype. The immune responses of yellowtail following injection of the 2 phenotypes differed: higher agglutinating titers were obtained with the $\mathrm{KG}$ + phenotype compared to the $\mathrm{KG}$ - phenotype. Thus, the cell surface may function as an anti-phagocytic factor in E. seriolicida and apparently affects its immunogenicity.
\end{abstract}

KEY WORDS: Enterococcus seriolicida - Seriola quinqueradiata Phagocytosis - Chemiluminescence . lmmune response

\section{INTRODUCTION}

Non-haemolytic streptococcal infection is one of the most common diseases in yellowtail Seriola quinqueradiata cultured in Japan (Austin \& Austin 1993). This infection has also been reported in the Japanese eel Anguilla japonica (Kusuda et al. 1978). Formerly, the causative agent of this disease was classified as Streptococcus sp., but recently it has been reclassified as Enterococcus seriolicida (Kusuda et al. 1991). Kitao (1982) reported that $E$. seriolicida could be serologically divided into 2 types, the so-called $\mathrm{KG}$ - and $\mathrm{KG}+$ phenotypes, but the biochemical characteristics of the 2 phenotypes were identical. This antigenic variation arose after subculturing fresh isolates on Streptococcus agar (KF Streptococcus agar; Difco Laboratories, Detroit, MI,

\footnotetext{
•E-mail: a0c201u@cc.miyazaki-u.ac.jp
}

USA) containing 2,3,5-triphenyltetrazolium chloride (TTC) or by successive subculturing on Todd Hewitt agar (TH agar; Difco). KG-phenotypes are so designated because, while they are agglutinated by anti$\mathrm{KG}$-serum, they are not agglutinated by antisera to the $\mathrm{KG}+$ strain (KG $7904 \mathrm{KG}+$ phenotype strain). In contrast, $\mathrm{KG}+$ strains can be agglutinated with both antisera to both KG+ and KG-phenotypes (Kitao 1982, 1993). Thus Kitao suggested that an envelope-like substance surrounding $\mathrm{KG}$-cells inhibited the agglutination with the anti-KG+ serum. The $\mathrm{KG}$ - phenotype (fresh isolate) strain is more highly pathogenic in yellowtail than the KG+ phenotype (Kitao 1982).

Virulence factors of the causative agent are still unknown in spite of the importance of this disease in aquaculture. In the present study, we examined the cell surface properties of both phenotypes of Enterococcus seriolicida. We also studied the immune responses of yellowtail injected intraperitoneally with the 2 phenotypes. 


\section{MATERIALS AND METHODS}

Bacterial strains. Enterococcus seriolicida strains isolated from diseased yellowtails in Japan are listed in Table 1. Stock cultures were maintained at $-70^{\circ} \mathrm{C}$ in $15 \%$ (vol/vol) glycerol-Todd Hewitt broth (THB; Difco). The bacteria were cultured in THB for $24 \mathrm{~h}$ at $30^{\circ} \mathrm{C}$. The phenotype was confirmed by rabbit antiserum raised against $\mathrm{KG}+$ cells. $\mathrm{KG}+$ cells were obtained following 3 passages of the $\mathrm{KG}$ - phenotype on KF Streptococcus agar (Difco) and were confirmed as such using $\mathrm{KG}+$ antiserum.

Preparation of anti-Enterococcus seriolicida $\mathbf{K G -}$ or KG+ phenotype rabbit antiserum. Cultures of both $\mathrm{KG}-$ and $\mathrm{KG}+$ strains were killed by the addition of $\hat{0} .3 \%$ formaidenyde (finai concentration). The celīs were washed with $0.85 \%$ saline solution, and resuspended in saline to an optical density of 1.0 at $620 \mathrm{~nm}$. The cell suspension was emulsified in an equal volume of Freund's complete adjuvant (FCA) and $1 \mathrm{ml}$ was inoculated in rabbits intramuscularly 3 times at 2 wk intervals. Blood was withdrawn and allowed to clot at $4^{\circ} \mathrm{C}$ for $1 \mathrm{~d}$. Serum was harvested and kept at $-80^{\circ} \mathrm{C}$ until required. Sera with a titer over 1:1240 against the homologous phenotype were used for the experiments.

Fish. The yellowtail used in this study were supplied by the Miyazaki Experimental Fisheries Station, Miyazaki, Japan. The mean body weight was $400 \mathrm{~g}$ and they were kept in $3000 \mathrm{l}$ tanks with seawater thermoregulated at $23^{\circ} \mathrm{C}$.

Electron microscopy. Both phenotypes of Enterococcus seriolicida NG8206 were cultured in THB at $30^{\circ} \mathrm{C}$ for $24 \mathrm{~h}$. Bacteria were fixed overnight with a final concentration of $2 \%$ glutaraldehyde in cacodylate buffer $(0.1 \mathrm{M}$, $\mathrm{pH}$ 7.2). After fixation, the cells were washed 5 times with the same buffer. Cells were dehydrated in increasing acetone concentrations from $30 \%$ to $100 \%$. They were subjected to critical point drying and then coated with a

Table 1. Strains of Enterococcus seriolicida used in this study and their properties

\begin{tabular}{|c|c|c|c|c|}
\hline Strain & Host & \multicolumn{2}{|c|}{$\begin{array}{c}\text { Antiserum } \\
\text { KG7409(-) KG7409(+) }\end{array}$} & Phenotype \\
\hline NG8206(-) & Yellowtail & + & - & $\mathrm{KG}-$ \\
\hline NG8206(+) & Yellowtail & + & + & $\mathrm{KG}+$ \\
\hline SA9201(-) & Yellowtail & + & - & $\mathrm{KG}-$ \\
\hline SA9201(+) & Yellowtail & + & + & $\mathrm{KG}+$ \\
\hline MZ9201(-) & Yellowtail & + & - & $\mathrm{KG}-$ \\
\hline MZ9201(+) & Yellowtail & + & + & $\mathrm{KG}+$ \\
\hline$K G 7409(-)$ & Yellowtail & + & - & $\mathrm{KG}-$ \\
\hline KG7409(+) & Yellowtail & + & + & $\mathrm{KG}+$ \\
\hline
\end{tabular}

layer of platinum palladium. Samples were examined with a scanning electron microscope (JEOL, JSM-35C, Tokyo, Japan) at an accelerating voltage of $25 \mathrm{kV}$

Bacterial adherence to hydrocarbon (BATH). The cell surface hydrophobicity was determined by the method of Rosenberg et al. (1980). Bacterial cultures were harvested, washed twice in Hanks' balanced salt solution (HBSS; Nissui), and suspended in this buffer at an optical density of 0.6 at $660 \mathrm{~nm}$. Three $\mathrm{ml}$ of bacterial suspension were layered with $1 \mathrm{ml}$ of $\mathrm{n}$-octane in glass tubes. After incubation at $37^{\circ} \mathrm{C}$ for $20 \mathrm{~min}$, specimens were agitated vigorously for $2 \mathrm{~min}$ and allowed to stand for 15 min to allow separation. The percent of partitioning in the hydrocarbon phase was calculated as

$\frac{A_{660} \text { (bact. susp.) }-A_{660} \text { (hydrocarbon-treated bact. susp.) }}{A_{660} \text { (bact. susp.) }} \times 100$

where $A_{660}=$ absorbance at $660 \mathrm{~nm}$.

Hemagglutination test. Hemagglutination was examined with live or formalin-killed bacterial suspensions. Both phenotypes were harvested, washed 5 times with physiological saline, and killed by adding formaldehyde to a final concentration of $0.3 \%$. These suspensions were washed 3 times with HBSS and then adjusted to an optical density of 1.0 at $620 \mathrm{~nm}$ in HBSS. Bacterial suspensions were tested for hemagglutination of sheep red blood cells (SRBC), horse red blood cells (HRBC), rabbit red blood cells (RRBC) or yellowtail red blood cells (YRBC) by reacting $50 \mu$ of bacterial suspension with $50 \mu \mathrm{l} 2 \%(\mathrm{v} / \mathrm{v})$ erythrocytes on a glass slide in a moist chamber. Strains were considered negative if visible agglutination did not occur within 10 min (Toranzo et al. 1983).

Opsonization of bacterial cells. Equal volumes of each bacterial suspension $\left(1.0 \times 10^{6}\right.$ cells $\left.\mathrm{ml}^{-1}\right)$ and yellowtail normal serum were mixed and incubated at $4^{\circ} \mathrm{C}$ for $60 \mathrm{~min}$. After incubation, the bacterial cells were washed 3 times with HBSS. Opsonized bacterial cells were resuspended in HBSS and adjusted to an optical density of 0.6 at $620 \mathrm{~nm}$.

Chemiluminescence assay. Kidney leucocytes from apparently healthy yellowtail were used in this study. The purification of the head kidney leucocytes was done according to Yoshida \& Kitao (1991). The head kidney leucocytes from 3 fish were mixed. Viable phagocytic cells were determined by trypan blue exclusion staining; the cells were resuspended to a concentration of $6.0 \times 10^{6}$ cells $\mathrm{ml}^{-1}$ in HBSS. The chemiluminescent assay was performed as described by Yoshida et al. (1993). Opsonized or non-opsonized phenotypes were used as the stimulant in the chemiluminescence assay. The chemiluminescence reactions were measured for 30 min by a TD4000M lumiphotometer (Laboscience) and then the peak values obtained with the $\mathrm{KG}$ - and $\mathrm{KG}+$ phenotypes were compared. 
Adherence or uptake by phagocytes (phagocytosis). The phagocytosis assay was performed as described elsewhere (Kitao et al. 1991). Briefly, purified head kidney leucocytes were adjusted to $6.0 \times$ $10^{6}$ cells $\mathrm{ml}^{-1}$ in HBSS and allowed to adhere to a coverglass. The coverglass was rinsed 3 times with HBSS and overlayed with an Enterococcus seriolicida suspension. The suspension had been adjusted to 0.6 optical density at $620 \mathrm{~nm}$ in HBSS and had been opsonized with yellowtail serum. The coverglasses were incubated at $25^{\circ} \mathrm{C}$ for $2 \mathrm{~h}$, rinsed with HBSS to remove free bacterial cells, and fixed with methanol. The cells were stained with Giemsa solution and the number of phagocytes containing or associated with more than 5 bacteria per 200 glass-adherent leucocytes was counted microscopically. All experiments were performed in triplicate.

Immune responses of yellowtail to the $\mathrm{KG}$ - and KG+ phenotypes. Bacterial cultures (NG8206) of each phenotypic strain were harvested, washed twice with $0.85 \%$ saline, and killed by adding formaldehyde to a
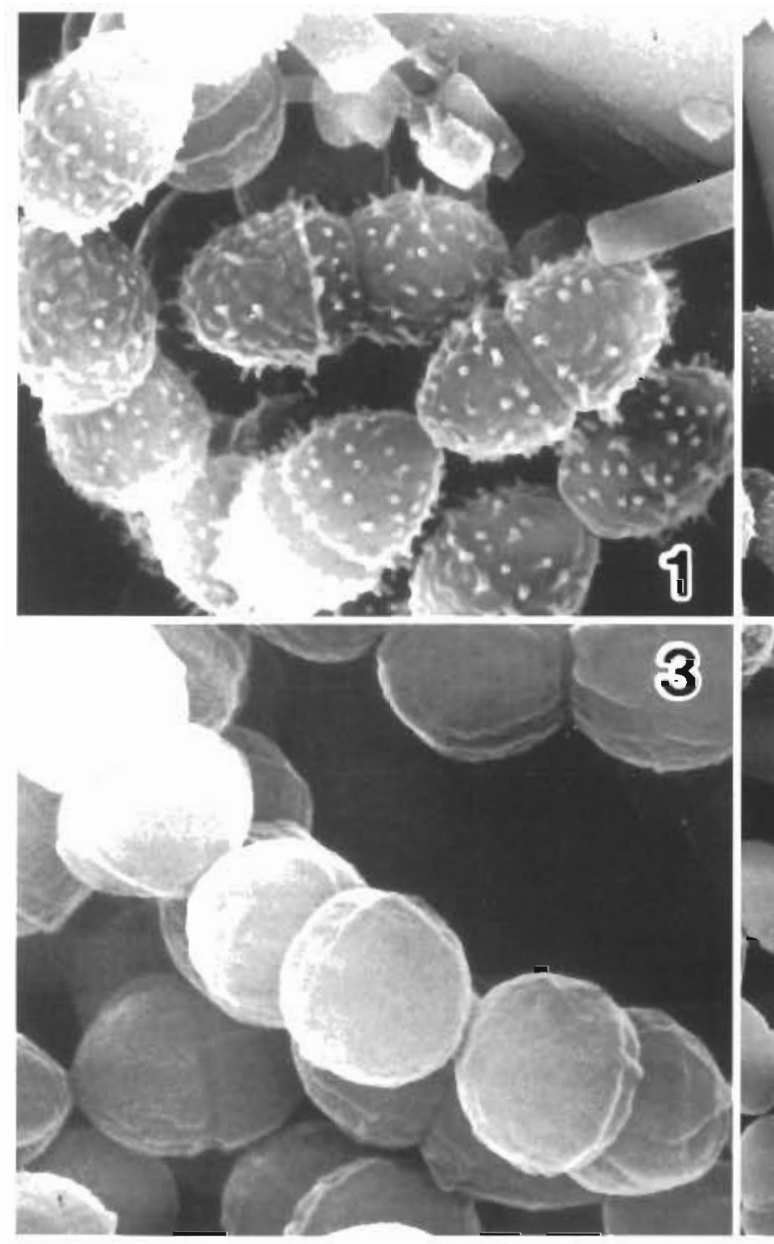

final concentration of $0.3 \%$ at $4^{\circ} \mathrm{C}$ for $24 \mathrm{~h}$. The bacteria were washed 3 times with physiological saline, and adjusted to an optical density of 1.0 at $620 \mathrm{~nm}$. Equal volumes of bacterial suspension and FCA were emulsified. One $\mathrm{ml}$ of bacterin was injected intraperitoneally per yellowtail. Blood was withdrawn by cardiac puncture 4,6 , and $8 w k$ after the immunization. The agglutinating titer of each serum against the phenotypes ( $\mathrm{KG}$ - and $\mathrm{KG}+$ ) was examined by the microtiter agglutination assay (Roberson 1990).

Agglutinating titers in cultured fish. Blood samples were obtained from 42 farmed yellowtail (1500 to 2000 g) from a fish farm in Oita Prefecture, Japan, in 1993. Serum was obtained from the blood after clotting at room temperature and centrifugation at $1000 \times g$ for $10 \mathrm{~min}$. The agglutinating titers of the serum samples for both phenotypes of Enterococcus seriolicida ( $\mathrm{KG}$ - and $\mathrm{KG}+$ ) were determined as mentioned above (Roberson 1990)

Statistical analysis. Statistical significance was assessed using Student's t-test.

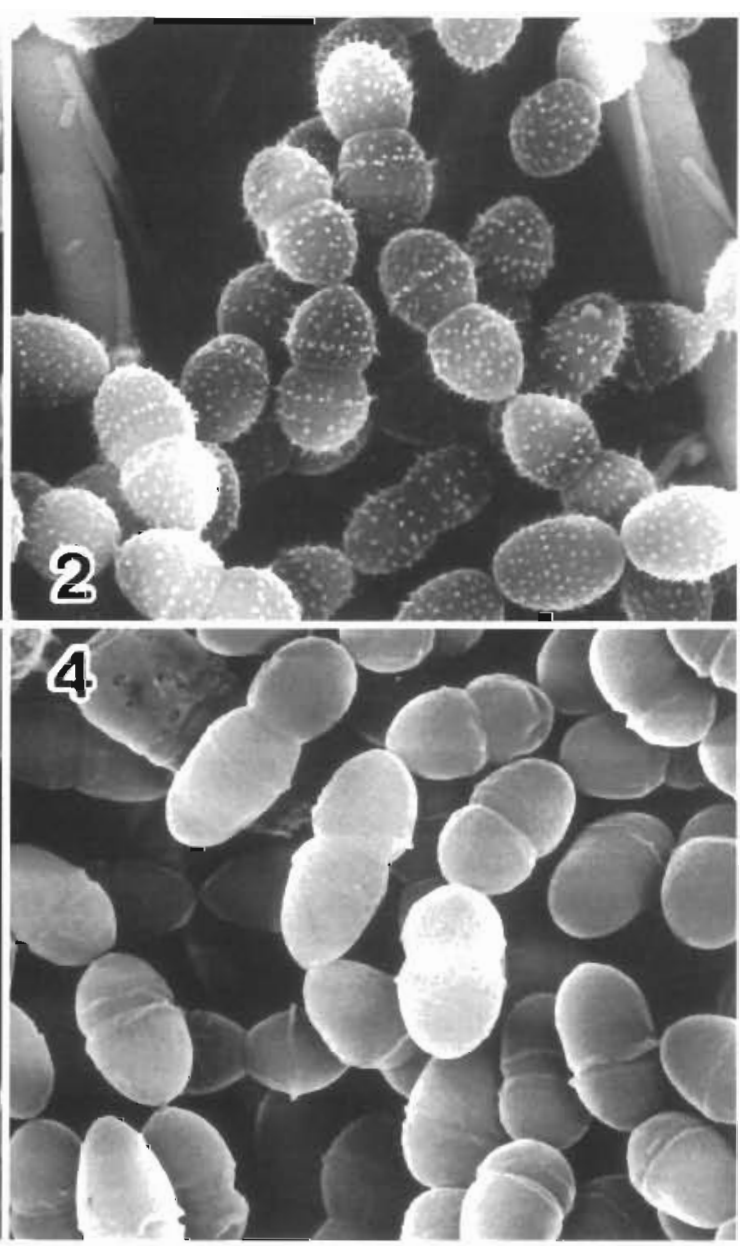

Fig. 1. Enterococcus seriolicida. Electron micrograph of $K G-(1,2)$ and $K G+$ phenotypes $(3,4)$ showing the difference in their cell surface morphologies. Magnifications are $\times 20000(1,3)$ and $\times 10000(2,4)$. KG+ phenotype cells showed smooth surface $(3$ and 4$)$, while clumps of some material were observed on the surface of the $\mathrm{KG}$ - phenotype 


\section{RESULTS}

Scanning electron microscopy. The scanning electron micrographs of Enterococcus seriolicida $\mathrm{KG}+$ and $\mathrm{KG}$ - phenotypes are shown in Fig. 1 The cell surface morphology of the KG+ phenotype was smooth, while $\mathrm{KG}$ - cells had a rough surface.

Serum agglutination. Enterococcus seriolicida $\mathrm{KG}+$ was agglutinated with both rabbit anti-KG+ and anti-KG-phenotype antiserum. However, the $\mathrm{KG}$ - phenotype was agglutinated only with the rabbit anti-KG-phenotype antiserum

Hydrophobicity of the cell surface. KG-phenotype strains partitioned into the hydrocarbon phase at rates of $1.0,2.5$, and $3.4 \%$. In contrast, $\mathrm{KG}+$ phenotype strains partitioned at rates of $23.4,13.2$, and $25.6 \%$. Thus, the cell surface of the $\mathrm{KG}$ - phenotype was more hydrophilic than that of the KG+.

Hemagglutination. Neither formaldehydetreated nor live cells of either phenotype agglutinated SRBC, HRBC, RRBC, or YRBC.

Chemiluminescence response. The chemiluminescence responses of yellowtail head kidney leucocytes to both phenotypes is shown in Fig. 2. The chemiluminescence responses of yellowtail head kidney cells were higher with the opsonized $\mathrm{KG}+$ phenotype than with the opsonized KG-cells. On the other hand, there was no significant difference in the chemiluminescence response between the non-opsonized phenotypes

Phagocytosis/adherence. Phagocytic activity was higher with $\mathrm{KG}+$ cells $(40,48$, and $37 \%)$ than with $\mathrm{KG}-$ cells $(20,21$, and $19 \%)$. The differences in these values were statistically significant $(p<0.05)$.

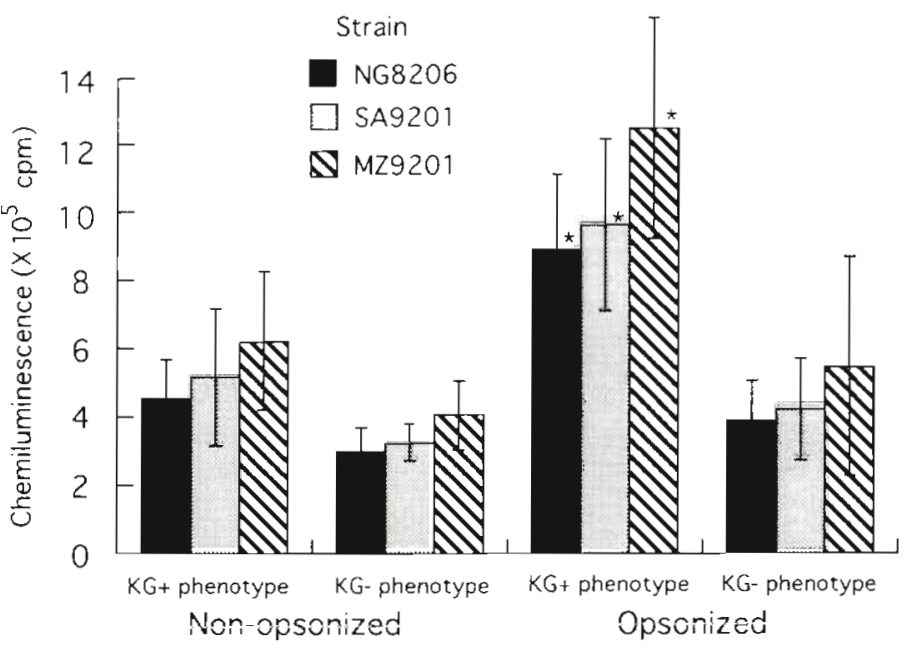

Fig. 2. Peak values of the chemiluminescent response of yellowtail Seriola quinqueradiata phagocytic cells against the $\mathrm{KG}$ - and $\mathrm{KG}+$ phenotypes of Enterococcus seriolicida. The peak chemiluminescence values of phagocytic cells against opsonized $\mathrm{KG}+$ phenotypes are significantly different from opsonized $\mathrm{KG}$ - phenotypes ( $p<0.05$ ). Error bars represent standard deviations calculated from triplicate experments

Immune response of yellowtail to $\mathrm{KG}-$ or $\mathrm{KG}+$ phenotypes. The serum agglutinating antibody titers of yellowtail injected with $\mathrm{KG}$ - or $\mathrm{KG}+$ phenotypes are shown in Fig. 3. Serum agglutinating titers against KG+ cells from the fish injected with $\mathrm{KG}+$ cells were high 4,6 , and $8 \mathrm{wk}$ after the immunization. The agglutinating titers against the $\mathrm{KG}$ - phenotype strain were low throughout this period. The serum agglutinating titers against KG- phenotypes from the fish injected with KGwere lower than those against the $\mathrm{KG}+$ phenotype strain $2 \mathrm{wk}$ and $6 \mathrm{wk}$ after the immunization $(\mathrm{p}<0.05)$; however, at 4 wk the difference was not significant.

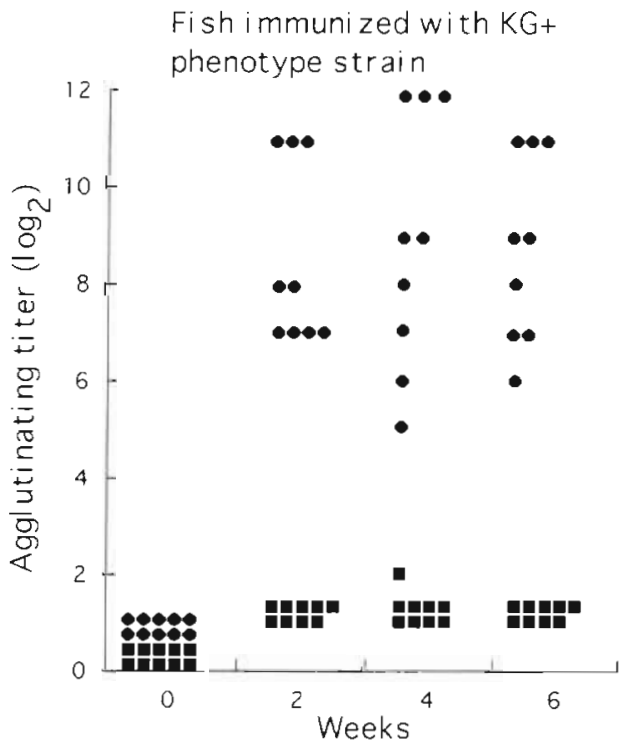

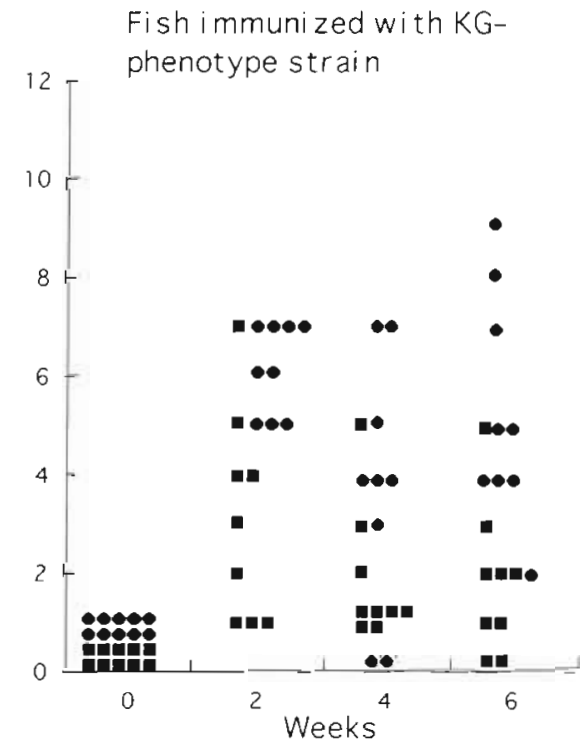

Fish immunized with $K G$ -

Fig. 3. Agglutinating titers against $\mathrm{KG}-(\mathbf{\square})$ and $\mathrm{KG}+(\bullet$ phenotype strains in sera from yellowtail Seriola quinqueradiata immunized with the $\mathrm{KG}-$ or $\mathrm{KG}+$ phenotype strains of Enterococcus seriolicida. Fish infected with the KG+ phenotype produced high titers of agglutinating antibodies against the $\mathrm{KG}+$ phenotype but not against the $\mathrm{KG}-$ phenotype. The agglutinating titers against $\mathrm{KG}$ - phenotype strains from fish injected with $\mathrm{KG}-$ phenotypes were lower than those against the $\mathrm{KG}+$ phenotype strain at 2 and $6 \mathrm{wk}$ after the immunization $(p<0.05)$ 


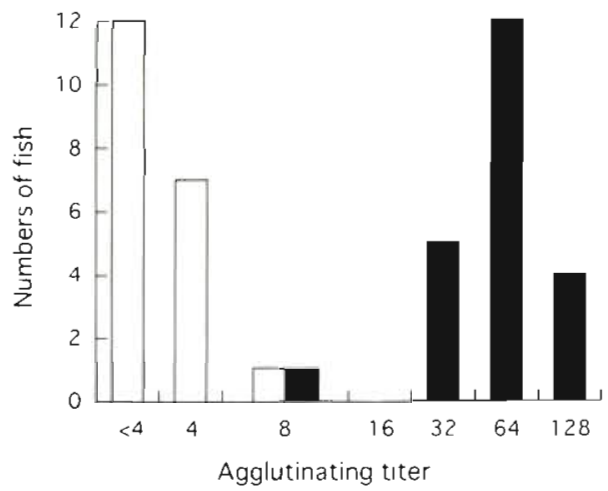

Fig. 4. Distribution of agglutinating titer against KG-phenotype (open bars) or $\mathrm{KG}+$ phenotype (filled bars) of Enterococcus seriolicada in sera obtained from farmed yellowtail Seriola quinqueradiata

Agglutinating titers in cultured yellowtail. The distribution of agglutinating titers in cultured yellowtail is shown in Fig. 4. Titers against the $\mathrm{KG}+$ phenotype ranged from $1: 8$ to $1: 128$, while against the $\mathrm{KG}-$ phenotype they ranged from $1:<4$ to $1: 4$.

\section{DISCUSSION}

In a previous study Kitao (1982) reported that antiserum prepared against Enterococcus seriolicida passaged several times on an artificial medium (KG+ phenotype) did not agglutinate fresh isolates (KGphenotype) from diseased fish. Kitao also found that most strains from diseased fish could not be agglutinated with the antiserum raised to the $\mathrm{KG}+$ phenotype. This suggested that the surface composition of E. seriolicida was unstable and could be changed easily on artificial culture. In the present study, we demonstrated the relationship between some cell surface properties and virulence of E. seriolicida.

Generally, opsonization of bacterial cells is dependent upon binding of complement or specific antibodies. Complement activation and binding on the surface of bacterial cells is considered to be of primary importance in phagocytosis and subsequent killing (Arduino et al. 1994a, b, Harvey et al. 1992). Streptococcus pneumoniae (Williams 1988), Staphylococcus epidermidis (Johnston et al. 1986), and Pseudomonas aeruginosa (Schwarzmann \& Boring 1971) possess capsules which inhibit opsonization by complement activation. In the present investigation, no visible capsule surrounding Enterococcus seriolicida was observed by light microscopy. However, scanning electron microscopy demonstrated a difference in the cell surface morphology between $\mathrm{KG}$ - and $\mathrm{KG}+$ phenotypes. The clumps on the surface of the $\mathrm{KG}$ - phenotype may rep- resent capsular material. KG-cells were more resistant to phagocytosis by yellowtail phagocytic cells compared with $\mathrm{KG}+$ cells and the chemiluminescence response to $\mathrm{KG}$ - phenotypes was also suppressed. The hydrophilic properties of $\mathrm{KG}$ - phenotypes may restrict adhesion to the phagocyte surface, thereby reducing phagocytosis. The respiratory burst, measured by the chemiluminescence response, can usually be induced by the attachment of foreign particles to the surface of phagocytic cells (Welch 1980). Chemiluminescence values of yellowtail phagocytic cells against $\mathrm{KG}$ phenotype did not differ significantly between opsonized and non-opsonized cells, suggesting that the surface material might have relevance to the virulence of $\mathrm{KG}$ - phenotypes by inhibiting complement binding to the bacterial surface

The cell surface hydrophobic properties of pathogenic bacteria are thought to play an important role in host cell attachment. In this study, the $\mathrm{KG}+$ phenotype strain of Enterococcus seriolicida showed high hydrophobic properties while the $\mathrm{KG}$ - phenotype strain was more hydrophilic. Most pneumococci are encapsulated and bind hexadecane poorly, suggesting that these organisms are not hydrophobic (Irvin 1990). This is similar to the finding with the KG-phenotype strain of E. seriolicida. In our laboratory it was found that the cell surface content of hydrophilic monosaccharides such as glucose, rhammnose, and sucrose was higher in the $\mathrm{KG}$ - phenotype strains than in the $\mathrm{KG}+$ phenotype strains (data not shown). This finding suggests that KG-phenotypes possess a cell surface capsule that is rich in hydrophilic monosaccharides and that causes this phenotype to be more hydrophilic.

Bacterial surface lectins, which are demonstrable because of their ability to cause agglutination of erythrocytes, are also important factors in host cell attachment (Courtney et al. 1990). However, tests of the hemagglutinating properties of Enterococcus seriolicida $\mathrm{KG}+$ or $\mathrm{KG}$ - phenotypes revealed no activity in either phenotype. Thus, we could not demonstrate a relationship between hemagglutinating activity of $E$. seriolicida and pathogenicity.

Finally, we investigated the specific immune response of yellowtail to the $\mathrm{KG}-$ and $\mathrm{KG}+$ phenotypes. $\mathrm{KG}+$ cells elicited higher serum agglutinating titers than the KG-phenotype. This suggests that the yellowtail has difficulty in recognizing the cell surface of $\mathrm{KG}-$ cells as foreign. Kitao (1983) reported that $\mathrm{KG}-$ phenotypes showed relatively high virulence compared with $\mathrm{KG}+$ by a challenge test. This finding is in accordance with the results of this study which showed that there was a significantly lower response in phagocytosis, chemiluminescence, and antibody production in yellowtail against the $\mathrm{KG}$ - phenotype compared with the KG+ phenotype. Further studies 
are in progress to document the presence of the cell surface putative capsule by thin section electron microscopy.

Acknowledgements. This study was supported by a grant-naid for scientific research from the Ministry of Education, Science and Culture of Japan.

\section{LITERATURE CITED}

Arduino RC, Murray BE, Rakita RM (1994a) Role of antibodies and complement in phagocytic killing of enterococci. Infect Immun 62:987-993

Arduino RC, Jacques-Palaz $K$, Murray BE, Rakita RM (1994b) Resistance of Enterococcus faecium to neutrophilmediated phaqocytosis. Infect Immun 62:5587-5594

Austin B, Austin DA (1993) Gram-positive bacteria: the lactic acid bacteria. In: Austin B, Austin DA (eds) Bacterial fish pathogens, 2nd edn. Ellis Horwood, New York, p 27-37

Courtney HS, Hasty DL, Ofek I (1990) Hydrophobicity of group A streptococci and its relationship to adhesion of streptococci to host cells. In: Doyle RJ, Rosenberg M (eds) Microbial cell surface hydrophobicity. American Society for Microbiology, Washington, DC, p 361-386

Harvey BS, Baker CJ, Edwards MS (1992) Contributions of complement and immunoglobulin to neutrophil-mediated killing of enterococci. Infect Immun 60:3635-3640

Irvin RT (1990) Hydrophobicity of proteins and bacterial fimbrie. In: Doyle RJ, Rosenberg $M$ (eds) Microbial cell surface hydrophobicity. American Society for Microbiology, Washington DC, p 137-177

Johnston GM, Lee DA, Regelmann WE, Gray ED, Peters G, Quie PG (1986) Interference with granulocyte function by Staphylococcus epidermidis slime. Infect Immun 54:13-20

Kitao T (1982) The methods for detection of Streptococcus sp. causative bacteria of streptococcal disease of cultured yellowtail, Seriola quinqueradiata, especially, their cultural, biochemical and serological properties. Fish Pathol 17: $17-26$

Kitao T (1983) Strain variation associated with pathogensis of Streptococcus sp., the causative agent of streptococcosis in cultured yellowtail, Seriola quinqueradiata. Proc 2nd Natl

Responsible Subject Editor: T. Evelyn, Nanaimo,

British Columbia, Canada
Pacific Aquaculture Symposium, Tokyo and Shimizu, Japan, 1983, Tokai University, p 231-242

Kitao $\Upsilon$ (1993) Streptococcal infection. In: Inglis V, Roberts RJ, Bromage NR (eds) Bacterial diseases of fish. Blackwell Scientific Publications, Oxford, p 196-210

Kitao T, Eshima T, Yoshida T (1991) Analysis of protective mechanisms in cultured ayu, Plecoglossus altivelis Temminck and Schlegel, administered Vibrio vaccine by the immersion method. J Fish Dis 14:375-381

Kusuda R, Kawai K, Salati F, Banner CR, Fryer JL (1991) Enterococcus seriolicida $\mathrm{sp}$. nov., a fish pathogen. Int $\mathrm{J}$ Syst Bacteriol 41:406-408

Kusuda R, Komatsu I, Kawai K (1978) Streptococcus sp. isolated from an epizootic of cultured eels. Bull Jap Soc Sci Fish 44:295

Roberson BS (1990) Bacterial agglutination. In: Stolen JS, Fletcher TC, Anderson DP, Roberson BS, van Muiswinkel WB (eds) Techniques in fish immunology. SoS Publications. Fair Haven. NJ. p 81-86

Rosenberg M, Gutnick D. Rosenberg E (1980) Adherence of bacteria to hydrocarbons: a simple method for measuring cell-surface hydrophobicity. FEMS Microbiol Lett 9:29-33

Schwarzmann S, Boring JR (1971) Antiphagocytic effect of slime from a mucoid strain of Pseudomonas aeruginosa. Infect Immun 3:762-767

Toranzo AE, Barja JL, Colwell RR, Hetrick FH, Crosa JH (1983) Haemagglutinating, haemolytic and cytotoxic activities of Vibrio anquillarum and related vibrios isolated from striped bass on the Atlantic coast. FEMS Microbiol Lett 18:257-262

Welch WD (1980) Correlation between measurement of the luminol-dependent chemiluminescence response and bacterial susceptibility to phagocytosis. Infect Immun 30: $370-374$

Williams P (1988) Role of the cell envelope in bacterial adaptation to growth in vivo in infections. Biochimie 70 : 987-1011

Yoshida T, Kitao T (1991) The opsonic effect of specific immune serum on the phagocytic and chemiluminescent response in rainbow trout, Oncorhynchus mykiss phagocytes. Fish Pathol 26:29-33

Yoshida T, Sakai M, Kitao T, Khlil SM. Araki S, Saitoh R, Ineno $T$, Inglis $V$ (1993) Immunomodulatory effects of the fermented products of chicken egg, EF203, on rainbow trout, Oncorhynchus mykiss. Aquaculture 109:207-214

Manuscript first received: March 20, 1995

Revised version accepted: November 8, 1995 